\title{
Assessment of Groundwater for Irrigation Using (IWQI) Model, Located in Al-Nimrud Region at Southeastern of Mosul City, Iraq
}

\author{
Abdul-Aziz Y. T. Al-Saffawi*1, Mohammad Amin Bhat ${ }^{2}$ and Azhar A. Albaker ${ }^{3}$ \\ ${ }^{I}$ Department of Biology, College of Education for Pure Sciences, University of Mosul, Iraq. \\ ${ }^{2}$ Department of Soil Science, CCS Haryana Agriculture University, Hisar, India \\ ${ }^{3}$ Department of Biology, College of Education for Girls, University of Mosul, Iraq. \\ *Corresponding Author Email: alsaffawia2025@uomosul.edu.iq \\ Received 13 January 2020, Revised 26 October 2020, Accepted 25 November 2020
}

\begin{abstract}
The study aimed to understand the quality of groundwater in Al-Nimrud region south-eastern part of Mosul city, Iraq. Groundwater samples from 10 wells were collected during the dry season and analyzed for their physical and chemical properties using standard laboratory methods. From the analyzed data, some parameters like sodium adsorption ratio (SAR), sodium percentage (Na\%), potenial salinity (PS), residual sodium carbonate (RSC), magnesium adsorption ratio (MAR), permeability index (PI) and Kellys ratio (KR) were calculated for each water sample to know the irrigational fitness and irrigation water quality index (WQI) was applied to the analytical results of the parameters to obtain a single value that was used to rank the groundwater at each well for agricultural uses. The results showed a high levels of salts for most of the water samples studied, where the average values of EC ranged between (1.64 to 5.069) dS. $\mathrm{m}^{-1}$. Also, the estimated parameters such as $\mathrm{Na} \%, \mathrm{SAR}, \mathrm{PI}, \mathrm{KR}$ were within the appropriate levels for irrigation, while the values of MAR, PS for most of the samples were within the inappropriate limits for irrigation. Also, the results of the WQI values showed that the groundwater quality falls between the category of severe to low restrictions, therefore the use of most of the water for irrigation in the study area is likely to lead to the problem of salinity in soils with heavy texture.
\end{abstract}

Keywords: IWQI, Groundwater quality, Groundwater of Al-Nimrud area.

\section{Introduction}

Water resources are facing many challenges due to the industrial, agricultural and social development witnessed in the world. These sources are exposed to pollution resulting from the dumping of civil, industrial and agricultural wastes as well as the scarcity of water quantities in many regions of the world, which led to the international public opinion to follow indicators indicating the decline in water quantity and increase pollution, where statistics indicate that water consumption in the last decade of the twentieth century doubled six times, equivalent to more than double the rate of population increase $[1,2]$. In 2025, one third of the world's population will face a serious water crisis due to the increasing need for water as a result of the increase in the world's population and the concomitant increase in water consumption of human activities. In addition to increasing wastewater and waste disposal to surface water resources, and thus increasing the pollution problems of water resources. Given the urgent need for water, efforts must be 
intensified for all responsible parties to reduce pollution problems and conduct continuous studies of water resources with the use of modern irrigation techniques to rationalize water consumption [3].

Salinity in soil and water is one of the most common problems in the world, especially in the arid and semi-arid regions. In Iraq, the area of land affected by salinity is approximately $70 \%$ of the total arable land.

Also, the high temperatures in the summer will increase the evaporation of soil water, which increases the accumulation of salinity in the soil.

In general, groundwater contains relatively high concentrations of dissolved salts compared to surface water due to exposure to rocks, geological layers, and biochemical reactions, which occur in these waters in addition to the possibility of contamination by agricultural fertilizers and civil and industrial waste that can seep into the groundwater through the permeable layers [2].

As a result, the high concentration of salts in irrigation water accumulates in the soil over the years to the extent that may lead to a reduction of plant production because the salts in the soil solution are absorbed only by the need for plant growth and do not run away from the accumulation in the area of roots growth. The problem of salinization of Iraqi soils does not modern but has existed since ancient times, such as the Sumerian and Babylonian civilizations [4]. Therefore, The consideration must be given to increasing the amount of irrigation water for washing salts from the root zone to reduce the risk of salinity [5], modern irrigation techniques should be used to determine the quality of irrigation water such as using water quality models (WQI), which is a good way to give easy information about water status (one value) instead of large numbers of water characteristics. WQI is a value reflecting the interrelated effects of different water attributes to give judgment on their applicability [6-10].

Therefore, the current study was to give a picture of the environmental situation of groundwater of the Nimrud district and its suitability for irrigation and give some recommendations and solutions.

\section{Materials and Methods}

The population of the study area is of an agricultural nature based on water resources available for irrigation, animals watering and civilian uses such as groundwater, and much of them is characterized by relatively high salts. The problem is compounded by high temperatures in the study area, the use of traditional irrigation methods, and the waste of water consumption [11-13]. The study area is characterized by loamy sandy soil and the following plants are frequently cultivated: celery, radishes, cauliflower, onions, tomatoes, cucumbers, legumes, potatoes and corn etc. Ten wells were identified in the Nimrud area of Al-Hamdaniya district, southeast of Mosul city and located between the latitude ( $\left.36^{\circ} 6.0^{\prime} 33.2^{\prime \prime}\right)$ to $\left(36^{\circ} 05^{\prime} 56^{\prime \prime}\right)$ north and longitude ( $\left.43^{\circ} 18^{\prime} 47.2^{\prime \prime}\right)$ and (43 ${ }^{\circ}$ $\left.17^{\prime} 48.2^{\prime \prime}\right)$ to the east at an altitude of $320 \mathrm{~m}$ above the sea level as shown in Fig. 1. The samples were collected during the dry season (4 replicates) at the rate of one sample per month from each site using cleaned polyethylene bottles. Some physical properties such as, odor and color were observed in the field and local residents were asked to about the history of the wells. The geology of the studied area is characterized by the presence of Al-Fatha (middle Miocene) formation which containing mainly of evaporated salts, anhydrite $\left(\mathrm{CaSO}_{4}\right)$, gypsum $\left(\mathrm{CaSO}_{4} \cdot 2 \mathrm{H}_{2} \mathrm{O}\right)$, limestone and marl etc., which leads to deterioration of the groundwater quality passing through in it $[14,15]$. 
Forty water samples were analyzed using standard methods [16]. Both $\mathrm{PH}$ and electrical conductivity $\left(\mathrm{EC}_{25}\right)$ were measured, calcium and magnesium ions $\left(\mathrm{Ca}^{+2}, \mathrm{Mg}^{+2}\right)$, sodium and potassium $\left(\mathrm{Na}^{+}, \mathrm{K}^{+}\right)$, carbonates and bicarbonates $\left(\mathrm{CO}_{3}^{-2}, \mathrm{HCO}_{3}{ }^{-}\right)$, sulphates $\left(\mathrm{SO}_{4}\right)$ and chlorides $\left(\mathrm{Cl}^{-}\right)$were estimated. As well, the sodium percentage $(\mathrm{Na} \%)$, sodium adsorption ratio (SAR), magnesium adsorption ratio (MAR), residual sodium carbonate (RSC), potential salinity (PS), permeability index (PI) and the Kelly ratio (KR) were calculated [17-19]. In addition to the assessment of the studied groundwater quality for irrigation purposes based on international classifications for each of the following characteristics: $\mathrm{EC}_{25}$, SAR, SSP, RSC, MAR, PS, KR [20-24].

\section{Model of Water Quality Index}

The application model of water quality WQI for irrigation purpose, which was developed by [25] have been identified as the most influential attributes in the quality of irrigation water. Then calculate the value of (qi) for each of the attributes of water according to the standards of the proposed irrigation water quality by the Advisory Committee of the University of California (UCCC) and standards provided by Ayers and Westcot [26], this mathematical model includes the following steps $[4,27]$.

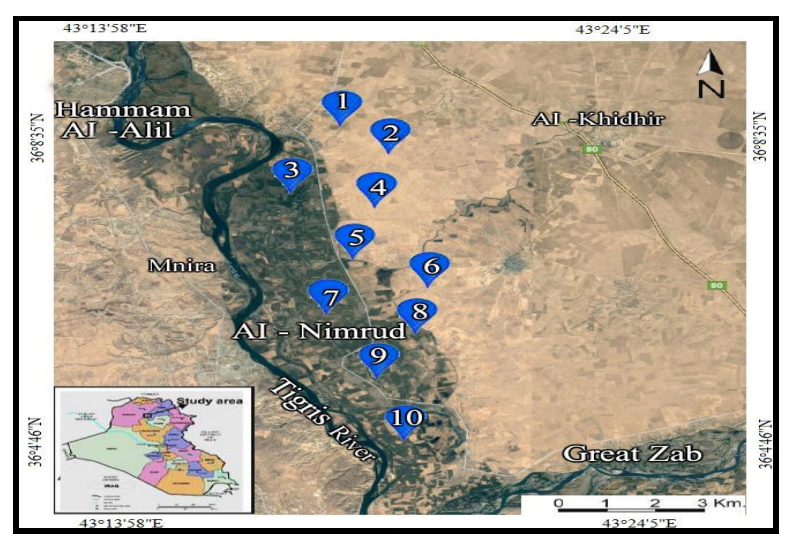

Figure 1. Map of the study area showing the studied wells sites.

\section{The First Stage}

Diagnosis of parameters of the most important and influential in determining the quality of the water for irrigation purposes.

\section{The Second Stage}

It is determined by measuring the quality values of (qi) for each parameter in accordance with the quality standards proposed by the Advisory Committee of the University of California as shown in Table 1. The quality rating (qi) values are calculated using the following equation [26]:

$\mathrm{q}_{\mathrm{i}}=\mathrm{qi}$ max.-[(Xij - Xinf. $) \times \mathrm{qi}$ amp. / X amp.]

$\mathrm{q}_{\text {imax }}$ : represents the maximum values of qi in the class, $\mathrm{X}_{\mathrm{ij}}$ represent the estimated

Table 1. Parameter limitation values for estimating the quality rating (qi) [26].

\begin{tabular}{|c|c|c|c|c|c|}
\hline$q \mathbf{i}$ & $\begin{array}{c}\mathrm{EC}_{25} \\
\mu \mathrm{S} / \mathrm{cm}\end{array}$ & SAR & $\begin{array}{c}\mathrm{Na}^{+1} \\
\mathrm{meq} / \mathrm{L}\end{array}$ & $\begin{array}{c}\mathrm{Cl}^{-1} \\
\mathrm{meq} / \mathrm{L}\end{array}$ & $\begin{array}{c}\mathrm{HCO}_{3}{ }^{-1} \\
\mathrm{meq} / \mathrm{L}\end{array}$ \\
\hline $100-85$ & $\begin{array}{c}\geq 200 \mathrm{Ec}> \\
750\end{array}$ & $\begin{array}{c}<3 \mathrm{SAR} \leq \\
2\end{array}$ & $<3 \mathrm{Na} 2 \leq$ & $<4 \mathrm{Cl} 1 \leq$ & $\begin{array}{c}<1.5 \leq \\
\mathrm{HCO}_{3} 1\end{array}$ \\
\hline $85-60$ & $\begin{array}{c}\geq 750 \mathrm{Ec} \\
1500>\end{array}$ & $<6 \mathrm{SAR} 3 \leq$ & $<6 \mathrm{Na} 3 \leq$ & $<7 \mathrm{Cl} 4 \leq$ & $\begin{array}{c}<4.5 \mathrm{HCO}_{3} \\
1.5 \leq\end{array}$ \\
\hline $60-35$ & $\begin{array}{c}\geq 1500 \mathrm{Ec} \\
3000>\end{array}$ & $\begin{array}{c}<12 \mathrm{SAR} \leq \\
6\end{array}$ & $<9 \mathrm{Na} 6 \leq$ & $<10 \mathrm{Cl} 7 \leq$ & $\begin{array}{c}<8.5 \mathrm{HCO}_{3} \\
4.5 \leq\end{array}$ \\
\hline $35-0.0$ & $\begin{array}{l}\geq 3000 \text { or } \\
<200 \mathrm{Ec}\end{array}$ & $\begin{array}{c}\mathrm{SAR}<2 \text { or } \geq \\
12\end{array}$ & $\mathrm{Na}<2$ or $\geq 9$ & $\begin{array}{c}\mathrm{Cl}<1 \text { or } \geq 1 \\
0\end{array}$ & $\begin{array}{l}\mathrm{HCO}_{3}< \\
1 \text { or } \geq 8.5\end{array}$ \\
\hline
\end{tabular}

Values for the parameter, $\mathrm{X}_{\mathrm{inf}}$ represents the corresponding value for the minimum limit of the class to which the parameter belongs to; $\mathrm{qi}_{\text {amp }}$ is the class ran,. In order to assess $X_{\text {amp }}$, of the last class of any parameter, the upper limit was considered to be the highest value determined in the physiochemical analysis of the irrigation water samples.

\section{Third Step}

Give weight (wi) for each recipe used in the model to be adjusted with the total sum of the weights equal to the correct one, and 
shown in the Table 2, and finally, calculate the value of the water quality from the following equation:

$\mathrm{WQI}=\sum_{\mathrm{t}=1}^{\mathrm{n}} \mathrm{qi} \cdot \mathrm{wi}$

Table 2. Weights (Wi) for the water quality parameters [26].

\begin{tabular}{lc}
\hline Parameters & Wi \\
\hline Electrical conductivity $\left(\mathrm{EC}_{25}\right)$ & 0.211 \\
Sodim ion $\left(\mathrm{Na}^{+}\right)$ & 0.204 \\
Chloride ion $\left(\mathrm{Cl}^{-1}\right)$ & 0.194 \\
Bicarbonate ion $\left(\mathrm{HCO}_{3}^{-1}\right)$ & 0.202 \\
Sodium Adsorption Ration (SAR) & 0.189 \\
$\Sigma$ & 1.000 \\
\hline
\end{tabular}

After calculating the value of WQI water quality is assessed by reference to the water quality Table 3 [26].

Table 3. Classification of water quality according to the values of (WQI).

\begin{tabular}{lccccc}
\hline WQI & $\leq$ & $70 \leq$ & $55 \leq$ & $\leq 55$ & $0.0 \leq$ \\
Values & 85100 & 85 & 70 & 40 & 40 \\
\hline Catogery & NR & LR & MR & HR & SR \\
\hline
\end{tabular}

NR: No restriction., LR: Low restriction. MR, Modrate restriction., HR: High restriction., SR: Severe restriction.

\section{Results and Discussion \\ Salinity Risk}

The electrical conductivity values represented by salinity damage are very important factors in determining the water quality used for irrigation. The results shown in Tables 4-5 indicate high electrical conductivity values ranging between $(1,629$ to 4.808$) \mathrm{dS} . \mathrm{m}^{-1}$ and at rates ranging between (1.641 to 4.158) dS. $\mathrm{m}^{-1}$. These values are higher than the values obtained by Al-Saffawi and AlSardar [28] in the study of groundwater quality at Abu Jarboaa and Aldarrawish villages east of Mosul city, which did not exceed (2.9) dS. $\mathrm{m}^{-1}$, and is consistent with the results obtained by Al-Saffawi [7] for the groundwater of Gleewkhan village, south of Mosul city, which ranged between (1.8 to 4.2$) \mathrm{dS} . \mathrm{m}^{-1}$. This elevation values may be attributed to the nature of the geological formations of the study area, which is characterized by the presence of lower Faris formation containing evaporative salts salts, gypsum and dolomite etc. which leads to deterioration of the quality of water passing through it [28].

\section{Permeability and Infiltration Risk}

The high concentration of sodium ions increases soil permeability problems, sodium works to dissipate soil aggregation, leading to deterioration of soil permeability. Also, the soil salinity role in the deterioration of soil permeability [1]. Table 4-5 shows that the SAR values ranged from 1.37 to 9.12 . This fluctuation in values depends on the concentration of sodium ions relative to the concentrations of calcium and magnesium ions. With the increase in SAR of irrigation water, lead to increasing the SAR in soil solution, which absolutely increases the exchangeable sodium from the soil [20]. In general, irrigation water, which has SAR value ranging from 0.0 to 10 , is suitable for irrigation and have no risk to soil permeability [21].

\section{Specific Ion Toxicity}

Sodium toxicity is expressed as SAR, high concentration of sodium ion in irrigation water has a toxic effects on the plants and shows the burns and death of tissue along with the leaf and adjacent to the outer edges, thus, the well water No. 3 and 10 are good quality for irrigation of plants while the rest of the studied wells between Slight to Moderate Restriction for sensitive plants. Chloride ions are considered to be toxic agents when present in high concentrations in irrigation water. 
Symptoms of toxicity initially appear as burns in the top of the leaves and then develop to their edges and in advanced cases, defoliation occurs. In general, well water no 10 is good for irrigation in terms of chloride toxicity and water wells no. $1,7,9$ are unsuitable for irrigation and the rest of the water are medium according to Ayers \& Westcot classification [29].

\section{Miscellaneous Effects}

For $\mathrm{pH}$, Table $(4,5)$ indicates that the values fluctuate slightly near the equalization state, ranging from 6.55 to 7.68 , so that the water studied is within the convenient irrigation limits, as for the bicarbonate ion, it plays a role in the acidity neutralization (ANC) when it is formed, without this capacity, negative impacts would have been worse for the aquatic ecosystem [15]. This high concentration is due to the interactions that occur during the passage in geological formations as in the following Eq [9]:

$\mathrm{CO}_{2}+\mathrm{H}_{2} \mathrm{O} \rightarrow \mathrm{H}_{2} \mathrm{CO}_{3} \mathrm{CaCO}_{3}+\mathrm{H}_{2} \mathrm{CO}_{3} \rightarrow$ $\mathrm{Ca}\left(\mathrm{HCO}_{3}\right)_{2}$
In general, the studied water in terms of the effect of bicarbonates of medium quality suitable for irrigation (low to moderate restriction) except well water No. 9 (severe restriction) according to classification [25], while $\mathrm{NO}_{3}-\mathrm{N}$ is a necessary nutrient for plant growth, increasing its concentration in water has serious effects on plants and consumers of these plants as well as on fish in aquatic environments [30]. Table $(4,5)$ shows that the concentration of nitrate-nitrogen ions ranged between 0.010 to $0.191 \mathrm{meq} . \mathrm{L}^{-1}$ at a rate not exceeding 0.172 meq. $\mathrm{L}^{-1}$. Generally, the water quality is good for irrigation according to [25]. As for sulfate ions, there is no specific damage to the soil and vegetation, but it contributes to increasing soil salinity [23]. It is noted from the tables that the levels of sulfate ions in studied water reached 52.6 meq. $\mathrm{L}^{-1}$, resulting in high potential salinity values reched to $37.3 \mathrm{meq} . \mathrm{L}^{-1}$, and thus will lead to deterioration of the irrigation water quality this increased in concentration may be ascribed to the nature of the geological formations of the study area rich in sulphate salts [15].

Table 4. Results of the physical and chemical properties of groundwater for the Nimrud area. Nineveh (meq. $L^{-1}$ except EC: $\left.d S . m^{-1}\right)$.

\begin{tabular}{|c|c|c|c|c|c|c|c|c|c|c|c|c|c|c|c|c|}
\hline Parameters & $\mathrm{pH}$ & $\mathrm{EC}_{25}$ & $\mathrm{Ca}$ & Mg & $\mathbf{N a}$ & $\mathbf{K}$ & $\mathrm{SO}_{4}$ & Cl & $\mathrm{HCO}_{3}$ & $\mathrm{NO}_{3}$ & SAR & MAR & $\% \mathrm{Na}$ & PS & KR & PI \\
\hline Min. & 6.55 & 3.57 & 19.2 & 20.2 & 13.4 & 0.10 & 39.2 & 10.0 & 4.88 & 0.037 & 3.33 & 42.4 & 25.8 & 26.0 & 0.349 & 21.0 \\
\hline Max. & 7.25 & 5.11 & 28.4 & 26.4 & 19.0 & 0.23 & 52.0 & 13.1 & 9.92 & 0.191 & 5.15 & 57.9 & 28.5 & 31.3 & 0.382 & 23.4 \\
\hline mean & 6.89 & 4.04 & 25.6 & 23.9 & 16.8 & 0.153 & 44.0 & 11.5 & 6.53 & 0.118 & 4.26 & 48.4 & 26.9 & 28.3 & 0.370 & 22.2 \\
\hline$S d \pm$ & 0.25 & 0.72 & 3.73 & 2.49 & 2.35 & 0.048 & 5.60 & 1.12 & 1.99 & 0.052 & 0.78 & 5.81 & 1.17 & 2.11 & 0.214 & 0.89 \\
\hline Min. & 6.89 & 3.63 & 20.4 & 20.2 & 12.0 & 0.130 & 42.8 & 8.35 & 5.74 & 0.020 & 2.49 & 43.3 & 20.4 & 29.7 & 0.260 & 25.0 \\
\hline Max. & 7.13 & 4.81 & 27.2 & 26.6 & 21.5 & 0.290 & 49.0 & 9.30 & 11.3 & 0.300 & 4.37 & 57.9 & 31.0 & 33.4 & 0.440 & 36.0 \\
\hline mean & 7.02 & 4.16 & 25.2 & 22.6 & 17.6 & 0.190 & 46.5 & 8.91 & 7.17 & 0.130 & 3.60 & 47.3 & 26.7 & 31.7 & 0.370 & 31.0 \\
\hline$S d \pm$ & 0.10 & 0.40 & 2.79 & 3.16 & 3.52 & 0.070 & 2.41 & 0.35 & 2.40 & 0.115 & 0.690 & 6.16 & 3.90 & 1.30 & 0.068 & 3.94 \\
\hline Min. & 7.56 & 1.79 & 4.80 & 6.40 & 4.17 & 0.090 & 14.4 & 4.80 & 2.36 & 0.018 & 1.41 & 36.0 & 19.1 & 12.0 & 0.240 & 26.6 \\
\hline Max. & 7.62 & 1.96 & 11.2 & 12.8 & 6.10 & 0.103 & 18.6 & 5.53 & 5.72 & 0.100 & 2.06 & 73.0 & 26.4 & 14.9 & 0.347 & 35.8 \\
\hline mean & 7.59 & 1.85 & 7.63 & 9.80 & 5.32 & 0.098 & 15.9 & 5.12 & 3.56 & 0.072 & 1.81 & 56.3 & 23.5 & 13.1 & 0.307 & 31.4 \\
\hline$S d \pm$ & 0.024 & 7.74 & 2.66 & 2.63 & 0.83 & 0.006 & 1.93 & 0.31 & 1.53 & 0.038 & 0.28 & 15.3 & 3.17 & 1.29 & 0.047 & 3.76 \\
\hline Min. & 6.73 & 3.62 & 11.4 & 15.2 & 10.6 & 0.054 & 21.9 & 7.33 & 6.70 & 0.042 & 2.51 & 43.0 & 22.5 & 17.7 & 0.297 & 28.4 \\
\hline Max. & 7.19 & 4.55 & 20.4 & 23.4 & 20.7 & 0.860 & 35.9 & 8.46 & 12.9 & 0.210 & 4.95 & 67.0 & 37.0 & 25.3 & 0.520 & 43.7 \\
\hline mean & 7.03 & 3.97 & 15.8 & 20.3 & 14.2 & 0.350 & 30.3 & 7.88 & 7.88 & 0.144 & 3.36 & 56.3 & 27.5 & 20.1 & 0.372 & 33.6 \\
\hline$S d \pm$ & 0.20 & 0.41 & 3.68 & 3.65 & 4.55 & 0.360 & 6.06 & 0.46 & 0.46 & 0.037 & 1.13 & 9.97 & 6.70 & 2.99 & 0.104 & 7.17 \\
\hline Min. & 7.15 & 1.63 & 3.19 & 6.40 & 9.20 & 0.064 & 8.10 & 6.27 & 4.76 & 0.068 & 4.12 & 66 & 45.0 & 10.5 & 0.860 & 57.0 \\
\hline Max. & 7.7 & 1.65 & 3.20 & 8.20 & 9.80 & 0.077 & 13.30 & 6.71 & 4.80 & 0.12 & 4.20 & 72 & 48.8 & 13.4 & 0.960 & 61.0 \\
\hline mean & 7.42 & 1.64 & 3.19 & 7.00 & 9.41 & 0.073 & 11.13 & 6.46 & 4.78 & 0.091 & 4.17 & 69 & 47.9 & 12.0 & 0.930 & 56.0 \\
\hline$S d \pm$ & 0.22 & 0.01 & 0.004 & 0.85 & 0.36 & 0.005 & 2.20 & 0.25 & 0.02 & 0.019 & 0.05 & 2.5 & 1.49 & 1.17 & 0.060 & 1.90 \\
\hline
\end{tabular}


Table 5. Results of the physical and chemical properties of groundwater for the Nimrud area. Nineveh (meq. $L^{-1}$ except EC: $d$ S.m ${ }^{-1}$ ).

\begin{tabular}{|c|c|c|c|c|c|c|c|c|c|c|c|c|c|c|c|c|}
\hline Parameters & pH & $\mathbf{E C}_{25}$ & Ca & Mg & $\mathbf{N a}$ & $\mathbf{K}$ & $\mathrm{SO}_{4}$ & $\mathbf{C l}$ & $\mathrm{HCO}_{3}$ & $\mathrm{NO}_{3}$ & SAR & MAR & $\% \mathrm{Na}$ & PS & KR & PI \\
\hline Min. & 7.30 & 2.158 & 2.20 & 6.8 & 9.96 & 0.09 & 13.0 & 3.30 & 3.30 & 0.021 & 3.66 & 46.0 & 39.0 & 10.8 & 0.67 & 49.0 \\
\hline Max. & 7.52 & 2.965 & 8.00 & 12.6 & 24.8 & 0.59 & 24.6 & 9.17 & 6.28 & 0.090 & 9.12 & 85.0 & 62.0 & 21.5 & 1.68 & 69.0 \\
\hline mean & 7.46 & 2.671 & 4.35 & 10.1 & 18.2 & 0.29 & 18.6 & 6.23 & 4.50 & 0.057 & 6.78 & 70.0 & 54.0 & 15.5 & 1.26 & 61.0 \\
\hline$S d \pm$ & 0.09 & 0.306 & 2.20 & 2.1 & 5.35 & 0.19 & 5.28 & 2.63 & 1.15 & 0.037 & 1.98 & 14.7 & 8.86 & 3.83 & 0.37 & 7.40 \\
\hline Min. & 7.52 & 3.208 & 6.39 & 12.8 & 26.2 & 0.16 & 28.6 & 12.6 & 2.78 & 0.020 & 6.77 & 58.0 & 55.5 & 27.7 & 0.99 & 53.0 \\
\hline Max. & 7.68 & 3.979 & 10.0 & 18.6 & 31.1 & 0.23 & 31.7 & 15.3 & 5.24 & 0.094 & 8.14 & 74.4 & 49.6 & 31.2 & 1.25 & 60.0 \\
\hline mean & 7.59 & 3.629 & 8.65 & 14.9 & 25.2 & 0.20 & 30.1 & 14.1 & 3.58 & 0.054 & 7.36 & 63.1 & 55.5 & 29.1 & 1.07 & 57.0 \\
\hline$S d \pm$ & 0.06 & 0.300 & 1.44 & 2.26 & 1.35 & 0.025 & 1.10 & 0.99 & 0.98 & 0.033 & 0.52 & 6.58 & 2.89 & 2.99 & 0.11 & 3.00 \\
\hline Min. & 7.13 & 2.768 & 4.00 & 12.0 & 17.8 & 0.14 & 24.9 & 8.07 & 3.76 & 0.010 & 5.37 & 54.5 & 44.5 & 20.9 & 0.81 & 50.2 \\
\hline Max. & 7.52 & 3.406 & 10.0 & 16.8 & 21.2 & 0.23 & 27.0 & 9.30 & 7.40 & 0.101 & 6.38 & 81.0 & 49.6 & 22.5 & 0.98 & 56.1 \\
\hline mean & 7.39 & 3.044 & 7.50 & 14.1 & 19.8 & 019 & 26.1 & 8.60 & 5.29 & 0.051 & 6.01 & 61.2 & 47.8 & 21.7 & 0.92 & 53.5 \\
\hline$S d \pm$ & 0.18 & 0.268 & 2.54 & 2.00 & 1.42 & 0.04 & 0.87 & 0.52 & 1.54 & 0.038 & 0.46 & 1.43 & 2.32 & 0.63 & 0.08 & 2.46 \\
\hline Min. & 6.87 & 5.711 & 12.0 & 29.0 & 16.5 & 0.14 & 38.6 & 10.7 & 7.10 & 0.044 & 3.45 & 66.2 & 26.5 & 30.0 & 0.36 & 31.6 \\
\hline Max. & 7.32 & 4.633 & 17.8 & 34.8 & 24.0 & 0.28 & 52.6 & 11.9 & 13.0 & 0.153 & 5.00 & 74.4 & 33.8 & 37.3 & 0.51 & 37.7 \\
\hline mean & 7.10 & 5.069 & 15.1 & 31.3 & 19.4 & 022 & 45.6 & 11.2 & 9.10 & 0.109 & 4.02 & 67.5 & 29.2 & 34.0 & 0.42 & 33.9 \\
\hline$S d \pm$ & 0.18 & 0.463 & 2.38 & 2.50 & 3.29 & 0.06 & 5.67 & 0.49 & 2.74 & 0.047 & 0.67 & 5.15 & 3.27 & 3.01 & 0.66 & 2.67 \\
\hline Min. & 7.32 & 1.728 & 7.6 & 8.4 & 4.5 & 0.033 & 19.7 & 3.39 & 5.54 & 0.166 & 1.37 & 39.0 & 17.2 & 12.6 & 0.21 & 23.2 \\
\hline Max. & 7.35 & 1.942 & 13.2 & 13.6 & 5.0 & 0.130 & 21.3 & 3.61 & 9.64 & 0.180 & 1.54 & 64.0 & 19.1 & 14.0 & 0.24 & 25.2 \\
\hline mean & 7.33 & 1.835 & 10.3 & 11.3 & 4.75 & 0.065 & 19.7 & 3.50 & 7.42 & 0.172 & 1.46 & 51.3 & 18.2 & 13.4 & 0.22 & 24.2 \\
\hline$S d \pm$ & 0.012 & 87.4 & 2.29 & 2.12 & 0.205 & 0.045 & 1.39 & 0.09 & 1.70 & 0.006 & 0.07 & 10.2 & 0.78 & 0.59 & 0.013 & 0.82 \\
\hline
\end{tabular}

The values of sodium percentage $(\% \mathrm{Na})$ and the permeability index (PI) were within the appropriate irrigation limits, As for, the concentration of residual sodium carbonate (RSC) in the studied water, no values were recorded, which reduces sodium damage due to the high concentration of calcium and magnesium ions compared to the concentration of bicarbonates ion [31], finally, the results of the study indicate the relative decrease in KR values attributed to higher levels of calcium and magnesium ions compared to the sodium ions concentration.

\section{Assessment of Groundwater for Irrigation Purpose}

In the current study groundwater was evaluated for irrigation purposes depended upon: Electrical conductivity, sodium adsorption, concentration of sodium ions, chlorides and bicarbonates) in the calculation of the WQI. The results shown in Table 6 indicate that the quality of water studied water for the wells no. $(9,8,7,4,2,1)$ were considered as Severe restriction quality type (SR). Therefore, use should be avoided under natural conditions, and sometimes possible to use low water salinity and high SAR with the addition of Gypsum, either highly saline water is used to irrigate high permeability soils with the addition of additional amount of water to prevent salts accumulation. Also, it is used to irrigate highly tolerant plants for salts except for the water with very low content of $\mathrm{Na}, \mathrm{Cl}, \mathrm{HCO}_{3}$ ions [26]. Water well no. $(6,5)$ is considered to be a high restriction water (HR), which are used to irrigate high permeability soils without compact layers, with a high frequency of irrigation within the specific dates of the program when using water containing on EC $2.0 \mathrm{dS} . \mathrm{m}^{-1}$ and SAR> 7.0, and suitable for irrigation of medium to high tolerant plants of salts, with special action to control the salts, except water with very low $\mathrm{Na}, \mathrm{Cl}$ and $\mathrm{HCO}_{3}$ values. 
Table 6. Results of water wells classification for irrigation purposes $[3,20,21,23,32]$.

\begin{tabular}{|c|c|c|c|c|c|c|c|c|c|c|}
\hline \multirow{2}{*}{ Wells } & \multicolumn{2}{|c|}{ IWQI } & \multirow{2}{*}{$\mathbf{E C}_{25}$} & \multirow{2}{*}{ SAR } & \multirow{2}{*}{$\% \mathrm{Na}$} & \multirow{2}{*}{ P.S } & \multirow{2}{*}{ MAR } & \multirow{2}{*}{ PI } & \multirow{2}{*}{ KR } & \multirow{2}{*}{$\mathrm{NO}_{3}$} \\
\hline & Values & Rating* & & & & & & & & \\
\hline 1 & 27.8 & SR & $\mathrm{C}_{4}$ & $\mathrm{~S}_{1}$ & Suitab & Poor & Suitab. & Good & Suitab. & NR \\
\hline 2 & 32.8 & SR & $\mathrm{C}_{4}$ & $\mathrm{~S}_{1}$ & Suitab & Poor & Suitab. & Good & Suitab. & N R \\
\hline 3 & 58.9 & MR & $\mathrm{C}_{3}$ & $\mathrm{~S}_{1}$ & Suitab & M- P & Unsuit. & Good & Suitab. & NR \\
\hline 4 & 3.40 & SR & $\mathrm{C}_{4}$ & $\mathrm{~S}_{1}$ & Suitab & Poor & Unsuit. & Good & Suitab & NR \\
\hline 5 & 51.8 & HR & $\mathrm{C}_{3}$ & $\mathrm{~S}_{1}$ & Suitab & M- P & Unsuit. & Good & Suitab. & N R \\
\hline 6 & 44.3 & HR & $\mathrm{C}_{4}$ & $\mathrm{~S}_{1}$ & Suitab & Poor & Unsuit. & Good & Unsuit & NR \\
\hline 7 & 23.9 & SR & $\mathrm{C}_{4}$ & $\mathrm{~S}_{1}$ & Suitab & Poor & Unsuit. & Good & Unsuit & NR \\
\hline 8 & 31.5 & SR & $\mathrm{C}_{4}$ & $\mathrm{~S}_{1}$ & Suitab & Poor & Unsuit. & Good & Suitab. & NR \\
\hline 9 & 14.5 & SR & $\mathrm{C}_{4}$ & $\mathrm{~S}_{1}$ & Suitab & Poor & Unsuit. & Good & Suitab. & NR \\
\hline 10 & 78.4 & LR & $\mathrm{C}_{3}$ & $\mathrm{~S}_{1}$ & Suitab & M- P & Unsuit. & Good & Suitab. & NR \\
\hline
\end{tabular}

As for well water, no (3) was of moderate restriction quality (MR), which may be used to irrigate soils with medium and high permeability, and suggests taking medium action to wash the salt and with moderate tolerance plants to salts. While water well no (10) was a low restriction (LR) quality when used for irrigation, which is used for irrigation sandy soils and medium permeability, recommend washing salts, and sodicity may occur in heavy soils, so, it should not be used to irrigate sensitive Salts plants [27]. When groundwater is evaluated for irrigation purposes according to the approved international classification, the water quality in terms of salinity is $70 \%$ of the studied samples of the very highly salinity water class $\left(\mathrm{C}_{4}\right)$ according to the classification of the American salinity laboratory (USSL), which are suitable for irrigation of plants that are very tolerant to salts planted in well-drained soils with a severe wash salts, except for well water samples no. (10, 5 and 3) of high salinity water class $\left(\mathrm{C}_{3}\right)$, which is suitable to irrigate plants tolerant of salinity and in good drainage soils, and that all studied groundwater samples from low sodium water class (S1) [32].

Water is also safe for irrigation for RSC and there is no risk from sodium ions in soil solution, water is also suitable for irrigation for SSP, PI, $\mathrm{NO}_{3}-\mathrm{N}$ [23]. As for the potential salinity (PS), $70 \%$ of the studied water samples are from poor water quality, and Moderate to Poor quality for water wells no. $10,5,3$ [23]. As for the values of the magnesium adsorption ratio (MAR) and according to Wilcoxs classification [3], 80\% of the groundwater samples are not suitable for irrigation, while the same proportion of water samples were suitable for irrigation for the values of the KR as shown in the Table 6.

\section{Conclusion}

The water sources studied were characterized by the relative increase of the most studied parameters, especially the values of the $\mathrm{EC}$ and the concentration of $\mathrm{Ca}, \mathrm{Mg}$, $\mathrm{Na}, \mathrm{Cl}$ and $\mathrm{SO}_{4}$ ions, which would affect water quality as a source of irrigation, $80 \%$ of IWQI values were poor quality for irrigation (SR to HR), while $20 \%$ of the values were medium to low restriction for irrigation (MR to $\mathrm{LR})$.

The majority of the studied water from very high salinity water (class $\mathrm{C}_{4}$ ), when used for irrigation, according to the USSL classification and poor quality for the values of potential salinity (PS), as well as $80 \%$ of the water samples are not suitable for irrigation for MAR. 
The majority of the studied groundwater is safe for RSC, KR, SSP, PI, $\mathrm{NO}_{3}-\mathrm{N}$.

Therefore, we recommend periodic monitoring of water resources in the region and the cultivation of plant species resistant to salts, considering the use of scientific and modern methods in irrigation operations.

\section{Acknowledgments}

We thank and appreciate the Presidency of Mosul University, represented by Professor Dr. Qusay Kamal Al-Din AlAhmadi and the Deanship of the College of Education for Pure Sciences for facilitating the provision of chemicals and conducting chemical tests and analyzes in the laboratories of Mosul University / Iraq. As well as $\mathrm{Mr}$ Mohammad Amin Bhat from Dept. of Soil Science CCS Haryana Agriculture University Hisar, India.

\section{References}

1. M. Sarfraz, N. Sultana and M. Jamil, Pak. J. Anal. Environ. Chem. 19 (2018) 79.

http://doi.org/10.21743/pjaec/2018.06.08

2. A. Y. T. Al-Saffawi and Y. T. M Alshuuchi, Int. J. Enhanced Res. Sci., Tech. Eng., 7 (2018) 76. http://www.erpublications.com

3. H. Moghimi, The Caspian Sea J., 10 (2016) 538.

https://pdfs.semanticsscholar.org http://dx.doi.org/10.4314/njt.v39i1.35

4. E. I. Newman, Applied ecology and environmental management. $2^{\text {ed }}$ Ed. Blackwell Pub. Co. USA. (2006) 393.

5. A. Y. T. Al-Saffawi and B. S. U. Ibn Abubakar, L. Y. Abbass and A. K. Monguno., Niger. J. Technol., 39 (2020) 632.
6. J. M. Ishaku, A. S. Ahmed and M. A Abubakar, Int. Res. J. Geol. Mining, 2 (2012) 54.

http://www.interesjournals.org/IRJGM

7. M. Latha, Int. J. Appl. Eng. Res., 14 (2019) 952.

ttp://www.ripublication.com

8. T. O. Farias, D. P. Lima and A. R. Balduíno, Int. J. Adv. Eng. Res. Sci., 6 (2019) 269.

https://dx.doi.org/10.22161/ijaers.6.5.35

9. G. H. Kahsay, T. Gebreyohannes, F. Woldemariyam and T. G. Emabye, Momona Ethiop. J. Sci., 11 (2019) 70. http://dx.doi.org/10.4314/mejs.v11i1.5

10. A. Y. T. Al-Saffawi, Pak. J. Anal. Environ. Chem., 20 (2019) 75.

http://doi.org/10.21743/pjaec/2019.06.10

11. A. Y. H. Kablan, I. O. S. Al-Hamdany and A. Y. T. Al-Saffawi, Alutroha J. Environ. Sci., 6 (2018) 45.

www.alutroha.com

12. E. A. Mohammad, E. A, Taha, S. F. Adnan and R. Haithem, Tikrit J. Pure Sci., 25 (2020) 47. http://dx.doi.org/10.25130/j.v25i2.957

13. A. Y. T. Al-saffawi, W. E. Al Sinjari and Y. A. Al-Taee, J. Eng. Appl. Sci., 14 (2019) 10706.

doi: 10.36478/jeasci.2019.10706.10710

14. K. T. Al-Yousbakey., A.M. Sulaiman and D. A. Ismaeel, The $9^{\text {th }}$ periodical Sci. Confer. of dam and water resources Res. Center. Mosul Univer. Iraq. 28-29 Nov. (2018) 201.

15. N. M. Al-Sardar, A. Y. T. Al-Saffawi, and R. A. A. Al-Shanona, Educat. J. Pure Sci., 27 (2018) 81.

https://www.iasj.net/iasj?func=issues\&ji d

16. APHA. "Standard method for examination of water and waste water". $20^{\text {th }}$ ed., Washington, DC, USA. (1998).

17. R. A. Talat, A. Y. R. Al-Assaf and A. Y. T. Al-Saffawi, IOP Conf. Series: $J$. 
Physics: Conf. Series, 1294 (2019) 072011: 1-10. doi:10.1088/1742-6596/1294/7/072011

18. G. Yasmin, D. Islam, M. D.T. Islam, M. Shoriot-Ullah and A. K. M. Adham Fund. Appl. Agric., 4 (2019) 632. doi: $10.5455 /$ faa.301258

19. P. Xu, W. Feng, H. Qian and Q. Zhang, Int. J. Environ. Res. Public Health, 16 (2019) 18.

www.mdpi.com/journal/ijerph

20. M. A. Bhat, S. A. Wani, V. K. Singh, J. Sahoo, D. Tomar, and R. Sanswal, J. Agric. Sci. Food Res., 9 (2018) 9.

https://www.researchgate.net/publication 1324536967

21. S. K. Pal, R. Ramprakash, M. A. Bhat and S. S Yadav, J. Soil Salin. Water Quality, 10 (2018) 157.

https://www.researchgate.net/publication $\underline{1331439081}$

22. O. M. Ramadhan, A. Y. T. Al-Saffawi and M. H. S. Al-Mashhdany, Int. J. Enhanced Res. Sci., Tech. Eng., 7 (2018) 63.

23. S. K. Nag and S. Das, Am.. J. Wat. Reso., 2 (2014) 81.

doi:10.12691/ajwr-2-4-2

http://pubs.sciepub.com/ajwr/2/4/2

24. A. J. Ememu and H. O. Nwankwoala, Eng. Heritage J., (GWK). 2 (2018) 14. http://doi.org/10.26480/gwk.01.2018.14. $\underline{18}$
25. R. S. Ayers and D. W. Westcot, (1985). Water quality for agriculture, FAO Irrigation and Drainage paper No 29, Rome.

26. A. C. Meireles, E. M. Andrade, L. C. Chaves, H. Frischkora and L. A. Crisostomo, Revista Ciencia Agronomica., 41 (2010) 349. www.ccarevista.ufc.br

27. A. Abbasnia, M. Radfard, A. H. Mahvi, R. Nabizadeh, M. Yousefi, and M. Alimohammadi, Data in Brief, 19 (2018) 623. www.elsevier.com/locate/dib

28. A. Y. T. Al-Saffawi and N. M. S. AlSardar, Int. J. Enhanced Res. Sci., Tech. Eng., 7 (2018) 6. http://www.erpublications.com

29. C. Simsek and O. Gunduz, Environ. Monit. Asses., 128 (2007) 277. https://www.researchgate.net/publication 16738017

30. G. Srivastaval and P. Kumar, Int. J. Res. Eng. Technol., 2 (2013) 609. www.elsevier.com/locate/dib

31. K. Ramesh and P. Pavithra, Int. J. Eng. Res. Appl., 6 (2016) 58. www.ijera.com

32. A. Richerd, "Diagnosis and Improvement of Saline and Alkali Soil", USDA Hand Book No. 60 (1969) 160. 